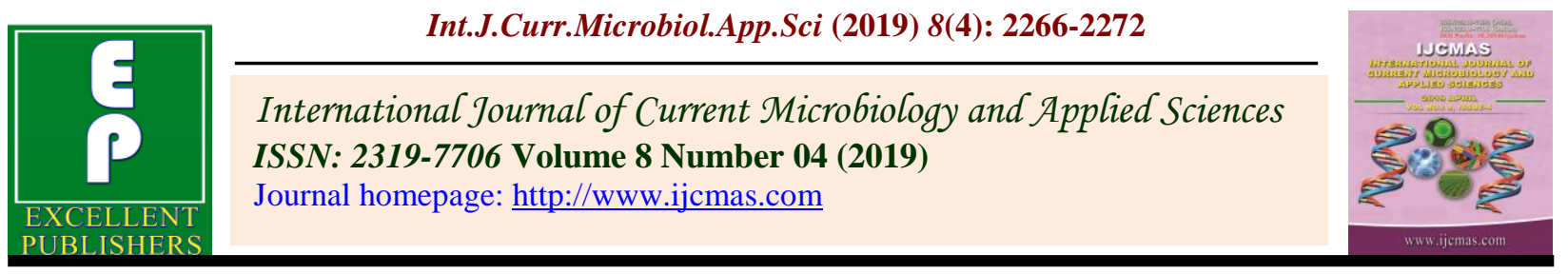

Original Research Article

https://doi.org/10.20546/ijcmas.2019.804.265

\title{
Performance Evaluation of a Power Operated Wetland Weeders for Paddy
}

\author{
N.K. Sathish Kumar* and A.P. Mohankumar \\ Department of Farm Machinery and Power Engineering, Agricultural Engineering College \\ and Research Institute (TNAU), Trichy, India, 621712 \\ *Corresponding author
}

\begin{tabular}{|c|c|}
\hline & A B S T R A C T \\
\hline Keywords & \multirow{4}{*}{$\begin{array}{l}\text { Generally farmers prefer manual weeding due to the lack of awareness about the } \\
\text { mechanical weeder. But manual weeding is a most laborious and time consuming } \\
\text { process. Nowadays mechanical weeders are being promoted to reduce drudgery, } \\
\text { time of operation and to overcome the lack of labours problem. The study has } \\
\text { been conducted on sandy loam and clay loam soils to evaluate the performance of } \\
\text { two mechanical power weeders i.e., Garuda power weeder and Japanese power } \\
\text { weeder. From the results, Garuda weeder has the highest weeding efficiency of } \\
68.62 \text { and } 76.92 \% \text { and lowest plant damage of } 24 \text { and } 13.33 \% \text { for sandy loam } \\
\text { and clay loam soils. Japanese weeder has highest and lowest field capacities of } \\
0.173 \mathrm{ha} \mathrm{hr}^{-1} \text { for sandy loam soil and } 0.067 \mathrm{hahr}^{-1} \text { for clay loam soil. The } \\
\text { performance index indicates that Garuda weeder and Japanese weeder is suitable } \\
\text { for sandy loam and clay loam soils respectively. }\end{array}$} \\
\hline $\begin{array}{l}\text { Plant damage } \\
\text { efficiency, } \\
\text { Performance index, } \\
\text { Weeding efficiency, } \\
\text { Effective field } \\
\text { capacity, Fuel } \\
\text { consumption }\end{array}$ & \\
\hline Article Info & \\
\hline $\begin{array}{l}\text { Accepted: } \\
\text { 17 March } 2019 \\
\text { Available Online: } \\
10 \text { April } 2019\end{array}$ & \\
\hline
\end{tabular}

\section{Introduction}

Rice is the staple food for more than half of the world's population. In paddy farming, weeds are competing with crops and it leads to decrease in yield. Weeds decline the crop yields from 15 to 50 percent influenced by the species, density and weeding period (Mirza et al., 2009). So, timely weeding operation is essential for the paddy crop to control the weeds and to upturn the productivity. About 33 percent cost of cultivation is consumed on weeding alone when supported with the manual weeding. There are different types of weeding followed in paddy cultivation viz., chemical weeding, manual weeding, mechanical weeding. Chemical weeding uses weedicides to kill the weeds and it is a little costliest method. Manual weeding is an accurate weeding method which results in a complete removal of weeds. Manual weeding is a time consuming and higher labour requirement process (Mahilang et al., 2017). Mechanical weeding is weed control technique that manage weed populations through remove, injure, kill, or make the growing conditions unfavorable for weeds. Efficient mechanical weeding for paddy is performed only on the System of Rice Intensification (SRI) methods of transplanted 
fields. It will not suitable for the conventionally transplanted fields. Keeping the above facts in view, selecting better weeder with region specific, commercially available two power weeders i.e., Garuda weeder and Japanese weeder were selected for performance evaluation under field conditions.

\section{Materials and Methods}

The study was conducted to evaluate the performance of two mechanical power weeders i.e., Garuda power weeder and Japanese power weeder. Both the weeders were evaluated for its performance during the weeding periods. The weeding was done at $20^{\text {th }}$ day after the transplanting of paddy in sandy loam soil at Tamil Nadu Agricultural University, Agricultural Engineering College and Research Institute, Kumulur $\left(10^{\circ} 55^{\prime} \mathrm{N}\right.$ and $78^{\circ} 49^{\prime}$ E) and another trail was done in clay loam soil at Tamil Nadu Rice Research Institute (TRRI), Aduthurai $\left(11^{\circ} 00^{\prime} \mathrm{N}\right.$ and $79^{\circ}$ $28 ' \mathrm{E})$. The row spacing adopted in the field was $20 \times 20 \mathrm{~cm} \& 20 \times 18 \mathrm{~cm}$. Various parameters were selected to evaluate the performance of selected power weeders on field conditions. The parameters are

Effective Field capacity

Weeding efficiency

Plant damage efficiency

Fuel consumption

Performance index

The specifications of selected two row power weeders are given in table 1.

\section{Effective field capacity}

It is the machines ability to do a job in a field conditions. It includes the time for turning in headlands, blade cleaning time when weeds clogged to the blade. It is expressed in hectare per hour $\left(\right.$ ha $\mathrm{h}^{-1}$ ). Effective field capacity is computed by using the formula (Keshavalu et al., 2017).

$\mathrm{EFC}=\mathrm{A} / \mathrm{T}$

Where

EFC - Effective field capacity (ha $\mathrm{hr}^{-1}$ )

A - Area covered (ha)

$\mathrm{T} \quad-$ Time taken to cover the area (h)

\section{Weeding efficiency}

It is the ratio between the number of weeds removed by the weeder to the number of weeds present before weeding. A plot of $1 \times 1$ $m$ was marked in the field and the weeds were counted before and after the weeding process. It is expressed in percentage $(\%)$. Weeding efficiency is computed by using the formula (Sabaji et al., 2014)

$\mathrm{WE}=\left(\left(\mathrm{W}_{1}-\mathrm{W}_{2}\right) / \mathrm{W}_{1}\right) \times 100$

Where

WE - Weeding efficiency (\%)

$\mathrm{W}_{1}$ - Number of weeds present before weeding

$\mathrm{W}_{2}$ - Number of weeds present after weeding

\section{Plant damage efficiency}

It is the ratio between the number of plants damaged by the weeder to the number of plants before weeding process. A plot of $1 \mathrm{x}$ $1 \mathrm{~m}$ was marked in the field and the plants were counted before and after the weeding process. It is expressed in percentage (\%). Plant damage is computed by using the formula (Sabaji et al., 2014).

$\mathrm{PD}=\left(\mathrm{P}_{1}-\mathrm{P}_{2}\right) / \mathrm{P}_{1} \times 100$

Where

PD - Plant damage (\%) 
$\mathrm{P}_{1} \quad$ - number of plants in $1 \mathrm{~m}^{2}$ plot

$\mathrm{P}_{2} \quad$ - number of plants damaged after weeding

\section{Fuel consumption}

It is the quantity of fuel refilled in the tank after a period of time. Initially a fuel tank is fully filled with fuel, the machine is allowed to run for 1 hour and refill the fuel tank using a measuring jar. It is expressed in litres per hour $\left(1 \mathrm{~h}^{-1}\right)$. Fuel consumption is computed by using the formula (Keshavalu et al., 2017)

$\mathrm{FC}=\mathrm{Q} / \mathrm{T}$

Where

FC - Fuel consumption $\left(1 \mathrm{~h}^{-1}\right)$

Q - Quantity of fuel refilled in the tank (l)

$\mathrm{T}$ - Total running time of an engine (h)

\section{Performance index}

It is the measure of machine performance how good the machine is adapted to a specific field condition with respect to power input. It is expressed in hectare per hp (ha hp $\left.{ }^{1}\right)$.Performance index was computed by using the formula (Sabaji et al., 2014)

$\mathrm{PI}=(\mathrm{EFC} \times(100-\mathrm{PD}) \times \mathrm{WE}) / \mathrm{P}$

Where

PI - Performance index (ha $\mathrm{hp}^{-1}$ )

EFC -Effective field capacity (\%)

PD - Plant damage (\%)

WE -Weeding efficiency (\%)

$\mathrm{P} \quad$-Power required to operate the weeder (hp)

\section{Results and Discussion}

Both the weeders were evaluated for its different evaluation parameters under different field conditions. The field operation of Garuda and Japanese power weeder is shown in figure 1 and 2 . The results observed were as follows

\section{Weeding efficiency}

From the field trail, the weeding efficiency were observed as for sandy loam and clay loam soils were 68.62 and $76.92 \%$ for Garuda weeder and 64.58 and $76.19 \%$ for Japanese weeder respectively. The weeding performance of Garuda and Japanese weeder in clay loam soil is higher when compared to sandy loam soil due to soil consistency. This leads to the easy cutting and removal of weeds.

\section{Plant damage efficiency}

From the field trail, the Plant damage efficiency were observed as for sandy loam and clay loam soils were 24 and $13.33 \%$ for Garuda weeder and 28 and $20 \%$ for Japanese weeder. The plant damage efficiency of Garuda and Japanese weeder in clay loam soil is lower when compared to sandy loam soil due to soil consistency. This leads to the easy cutting action of blades to follow its trajectory, hence the weeders doesn't deflect from the passage line. So the efficiency of plant damage gets lowered.

\section{Effective field capacity}

From the field trail, the effective field capacity were obtained as for sandy loam and clay loam soils were 0.160 and 0.090 ha $\mathrm{h}^{-1}$ for Garuda weeder and 0.173 and $0.067 \mathrm{ha} \mathrm{h}^{-}$ ${ }^{1}$ for Japanese weeder. The effective field capacity of Garuda and Japanese weeder in clay loam soil is lower when compared to sandy loam soil due to field conditions. Field condition reduces the forward action of the weeders by not providing sufficient traction to the blades. 
Table.1 Specifications of machine used in field trial

\begin{tabular}{|c|c|c|c|}
\hline \multirow[t]{2}{*}{ S.No } & \multirow{2}{*}{ Description } & \multicolumn{2}{|c|}{ Specifications } \\
\hline & & Garuda Weeder & Japanese Weeder \\
\hline 1 & Model & Sharp Garuda 3PT 250 & \\
\hline 2 & Power, kW & 1.4 & 1.4 \\
\hline 3 & Transmission type & Worm and wheel type gear & Worm and wheel type gear \\
\hline 4 & Width of cut, m & 0.4 & 0.4 \\
\hline 5 & Blade type & L type & Finger type \\
\hline 6 & No. of rows & 2 & 2 \\
\hline 7 & No. of blades on each flange & 8 & 12 \\
\hline
\end{tabular}

Fig.1 Field operation of Garuda weeder

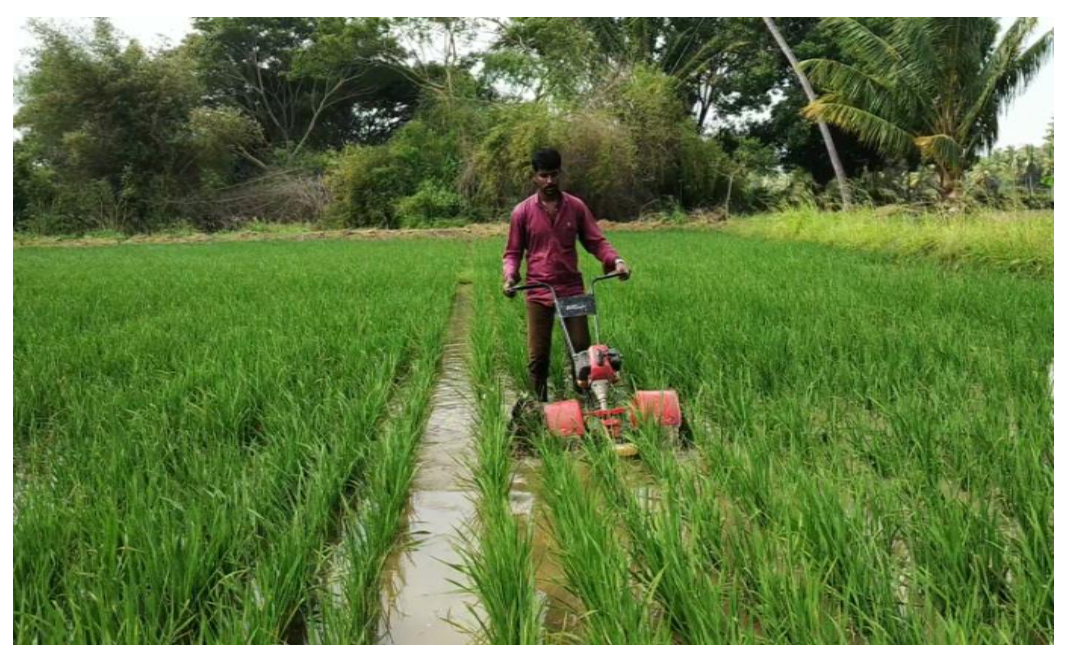

Fig.2 Field operation of Japanese weeder

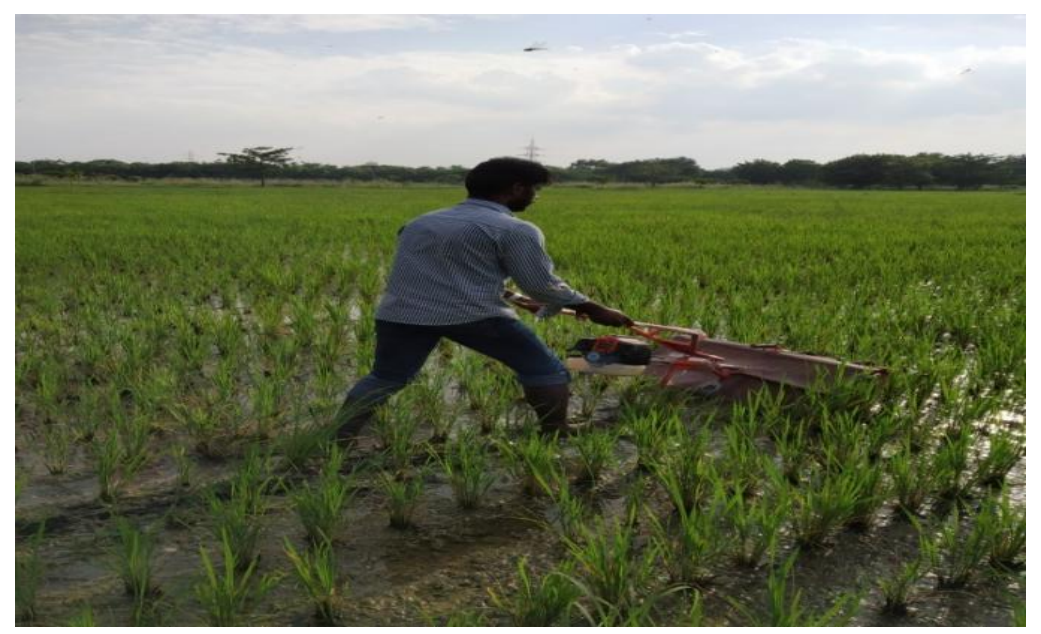



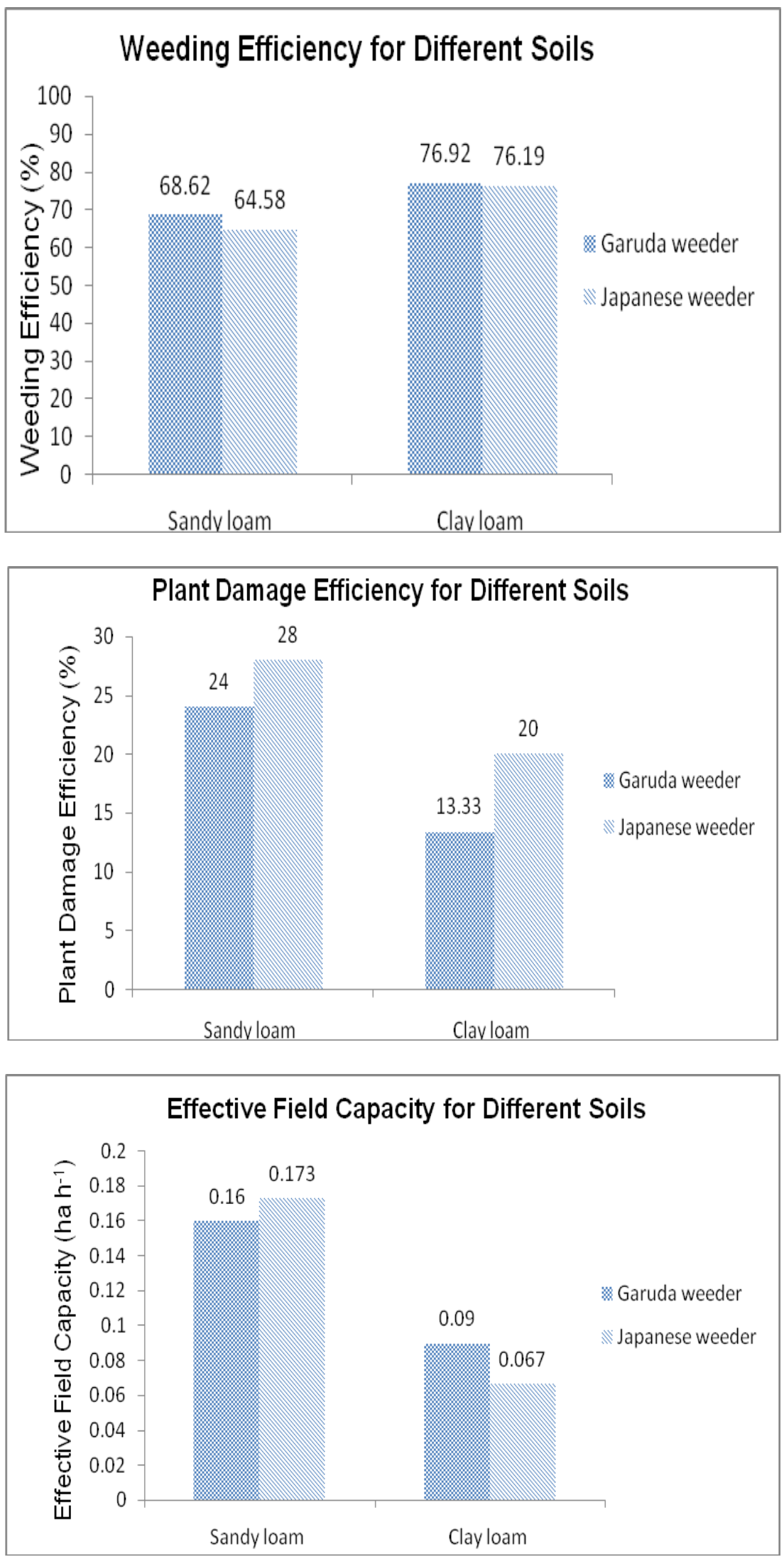

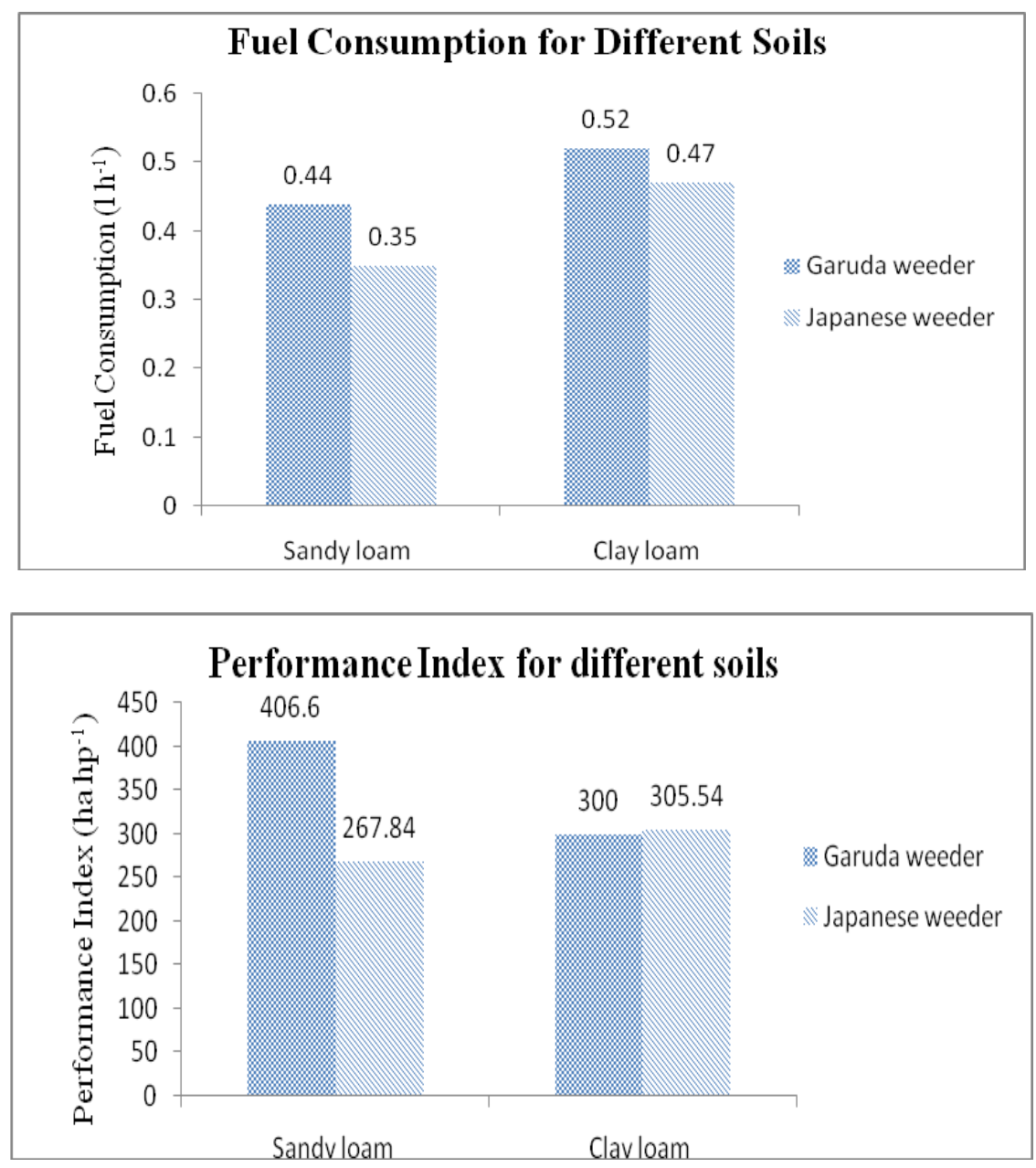

\section{Fuel consumption}

From the field trail, the fuel consumption were observed as for sandy loam and clay loam soils were 0.44 and 0.521 ph for Garuda weeder and 0.35 and 0.471 ph for Japanese weeder. The fuel consumption of Garuda and Japanese weeder in clay loam soil is lower when compared to sandy loam soil due to field conditions. Field condition reduces the forward action of the weeders by not providing the traction to the blades.

\section{Performance index}

From the field trail, the performance index were recorded as for sandy loam and clay loam soils were 406.60 and $300 \mathrm{ha} \mathrm{hp}^{-1}$ for Garuda weeder and 267.84 and 305.54ha hp
${ }^{1}$ for Japanese weeder. The performance index of a Garuda weeder indicates that it is suitable for sandy loam soils and performance index of a Japanese weeder indicates that it is suitable for clay loam soils.

In conclusion, two power weeders were evaluated under two different soil conditions i.e. sandy loam and clay loam soil. Weeding efficiency, Plant damage, Fuel consumption, Effective Field Capacity and Performance Index were evaluated. From the results, Garuda weeder has the highest weeding efficiency of $68.62 \& 76.92 \%$ and lower plant damageof $24 \& 13.33 \%$ for sandy loam and clay loam soils. Japanese weeder has highest field capacity of $0.173 \mathrm{ha} \mathrm{hr}^{-1}$ for sandy loam soil and in the clay loam soil it has the lower field capacity of $0.067 \mathrm{ha} \mathrm{hr}^{-1}$ due to the 
sinkage problem. The performance index of a Garuda weeder indicates that it is suitable for sandy loam soils and performance index of a Japanese weeder indicates that it is suitable for clay loam soils.

\section{References}

Mirza Hasanuzzaman, M., Ali M H, Alam M M, Akther M, Alam K F. (2009). Evaluation of pre-emergence herbicide and hand weeding on the weed control efficiency and performance of transplanted Aus rice. AmericanEurasian J. Agron, 2(3): 138-143.

Keshavalu, Prasan Patil, B, Raghavendra V and Shafat khan. (2017). Performance evaluation of wetland power weeder for paddy. Asian Journal of Agricultural Extension, Economics and Sociology, 18(3): 1-8.

Kumar, Anil Kumar and Dileep Sean. (2017). Performance evaluation of power weeder under dry and wetland conditions. International Journal of Agriculture Innovations and Research, 6(2).

Mahilang, Choudhary, Victor, Naresh and Sonboier. (2017). Design and development of power operated paddy weeder for rice. Current Journal of Applied Science and Technol, 24(5): 1-7.

Narwariya, Tiwari and Shrivasatava. (2016). Performance evaluation of different manually operated weeding equipment for paddy crop in versitols. Ecology, Environment and Conservation, 22:S357 - S363.

Sabaji, T D., Sahoo P K, Dipankar De and Mir Asif Iquebal (2014). Design and development of ridge profile power weeder. Journal of Agricultural Engineering, 51(4).

\section{How to cite this article:}

Sathish Kumar, N.K. and Mohankumar, A.P. 2019. Performance Evaluation of a Power Operated Wetland Weeders for Paddy. Int.J.Curr.Microbiol.App.Sci. 8(04): 2266-2272. doi: https://doi.org/10.20546/ijcmas.2019.804.265 